\title{
An Analysis of the Perception and Use of Ecodesign Practices by Companies
}

\author{
Mauro Maia Laruccia ${ }^{\dagger}$ \\ Pontifical Catholic University of São Paulo/ University of Sorocaba \\ Mamerto Granja Garcia ${ }^{\Omega}$ \\ Pontifical Catholic University of São Paulo
}

\begin{abstract}
This article investigates aspects related to the adoption of ecodesign practices by companies. It is descriptive in nature, based on a quantitative survey. We considered 10 indicators of ecological design principles and ecodesign practices, obtained from a review of the relevant literature, and administered a questionnaire to 340 respondents on the set of indicators investigated. We conclude that in addition to meeting legal requirements, the adoption of ecodesign practices benefits the environment and society as a whole. It also enhances firms' social image by publicizing their concern for environmental preservation and reduces the use of materials and consumption of energy.
\end{abstract}

Keywords: Ecodesign. Environmental management. Sustainability.

${ }^{\dagger} \mathrm{PhD}$ in Communication and Semiotics from Pontifical Catholic University of São Paulo (PUCSP)

Institution: Professor at the School of Economics, Administration and Accounting of PUCSP and in the Master's Program in Communication and Culture of the University of Sorocaba.

Address: Av. Chibarás, São Paulo - SP - Brazil

E-mail: mauro.laruccia@gmail.com

Telephone: (11) 5052-2872
$\Omega \mathrm{PhD}$ in Social Sciences from Pontifical Catholic University of (PUCSP) Institution: Professor at the School of Economics, Administration and Accounting of PUCSP.

Address: Rua Monte Alegre, 984, sala 122, São Paulo - SP - Brazil

E-mail: mamerto.garcia@gmail.com

Telephone: (11) 3113-9498

Note from the Editor: This article was accepted by Emerson Mainardes. 


\section{INTRODUCTION}

$\mathrm{n}$ important factor that contributes to the environmental degradation that

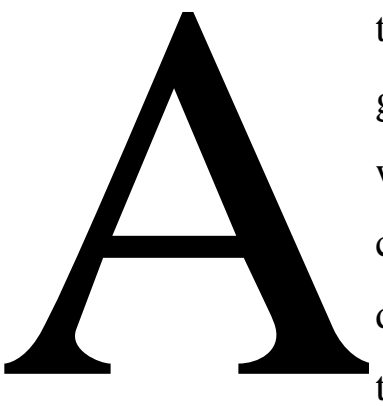
threatens the planet today is the growing production and consumption of goods and services. Related factors include the lifestyle of some societies, which demands intensive use of resources, especially in developed countries, the rapid growth of emerging economies, the aging population in developed countries, economic inequality between regions of the planet and the ever shorter life cycle of products (CHEHEBE, 2002; KAZAZIAN, 2005; MAXWELL; SHEATE; VAN DER VORST, 2006).

Environmental analysts emphasize the need to consider the environmental cost of products against the revenues they generate and stress that to promote sustainability, environmental questions must be viewed as part of the global process of developing products (LUTTROPP; LAGERSTEDT, 2006).

Concepts such as ecological design (or design for the environment), cleaner production and development of sustainable products promote the use of environmentally friendly techniques in the conception, design and manufacture of products (BYGGETH; BROMAN; ROBERT, 2007).

Ecodesign has been defined as "a concept that integrates multifaceted aspects of design and environmental considerations" into product development in order to "create sustainable solutions that satisfy human needs and desires" (KARLSSON; LUTTROPP, 2006).

The factors that motivate the adoption of ecological conception are not limited to environmental benefits. Firms that implement these practices also can reduce costs, obtain competitive advantages, improve their corporate image and the quality of their products, and even reduce the legal requirements to which they are subject (VERCALSTEREN, 2001).

Most large companies already pay heed to ecodesign principles as a way to promote competitiveness and improve their public image. On the other hand, most small and mediumsized enterprises (SMEs) have not yet recognized the benefits and possibilities that ecodesign and ecological considerations have to offer (VERCALSTEREN, 2001). As a result, SMEs do not customarily integrate ecodesign in their product development processes (LE POCHAT; BERTOLUCI; FROELICH, 2007).

Ecodesign tools, however, pose a difficulty to firms in general, and SMEs in particular: the use of the majority of these tools requires a high degree of specialization. Thus, to carry 
out ecodesign with the most useful and accessible tools, it is necessary to help designers to articulate them with more conventional development tools (LE POCHAT; BERTOLUCI; FROELICH, 2007; LOFTHOUSE, 2006; RAO, 2004). In this sense, firms oriented to innovation and design seek ways to cut costs or promote a revolution in their products. For this reason, designers committed to sustainability or ecodesign propose the joining of esthetics with functionality, with focus on reduction of environmental impacts.

Based on this scenario, the aim of this article is to investigate the principles and practices adopted by ecodesign, among them the choice of materials with low environmental impact (including packaging materials), design of simple, durable and/or multifunctional products, use of renewable energy sources, and prevention of accidents. This investigation is pertinent because Brazil's sustainable economic development requires changes in environmental behavior, with impacts on the development of products by firms to include "green" or ecodesign aspects in the projects for new products. This article is organized in six sections including this introduction. In the next section we present ecodesign concepts in the business context, while in the third section we describe the ecodesign principles and practices. In the fourth we discuss the methodological aspects and report the results found in the fifth part. The sixth section contains our conclusions and recommendations for future research.

\section{CONCEPT OF ECODESIGN}

Kazazian (2005) focuses on the ecological conception, defined as the application of ecodesign concepts. With this approach, the environment is considered to have equal importance as factors such as technical feasibility, control of costs and market demand. The ecological conception can involve three different levels of intervention of ecodesign in the conception of a product: (1) optimization to reduce environmental impact; (2) more intense development efforts, such as product modification; and (3) "radical" intervention efforts, such as substitution of products or services with different ones.

Boks (2006) stresses the importance of product designers, especially their original position and ability to influence environmental strategies. Designers can have a fundamental impact when they expand the focus of their efforts, giving the environment a leading position in defining the parameters for product development.

Karlsson \& Luttropp (2006) note that the ecological concept incorporates priorities related to sustainability in the global business scenario. The "eco" element, in the ecological conception, can refer both to the economy (reflecting a business orientation) and ecology (reflecting the importance of environmental aspects) (see Figure 1). 


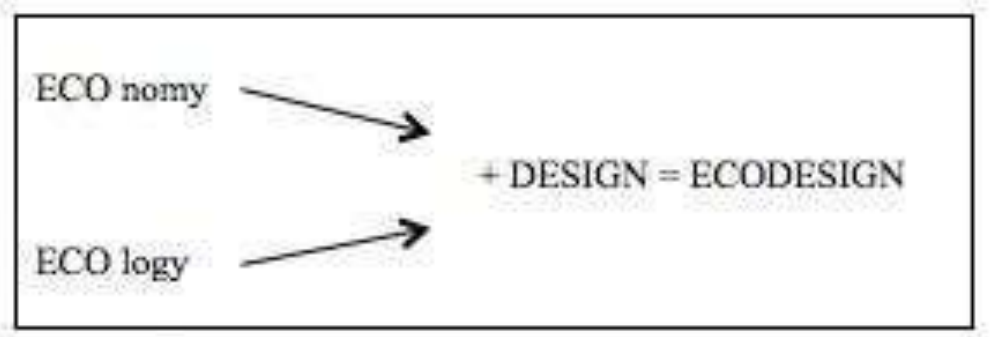

Figure 1: Origins of the word "Ecodesign"

Source: Karisson \& Luttropp (2006).

According to Boks (2006), the factors associated with the execution of ecodesign are related to commercial aspects, such as personalization, organization and communication. The most serious obstacles are associated with social and institutional questions, such as the differences of vision between advocates and implementers of ecological conception, organizational complexity and lack of cooperation.

As observed by Theyel (2000), although certain companies have adopted a range of tools for environmental management, their organizational strategic planning does not always incorporate fundamental environmental considerations.

According to Bahmed, Boukhalfa \& Djebabra (2005), some of the most important factors for success of ecological conception projects (applying the ecodesign concepts) are group motivation and management, use of working teams and a standard mechanism for product design, initial launch of the action project and its communication, and the need to provide training and achieve technological development with the help of experts who are well informed about ecological conception. These authors also indicate various risk factors for failure of execution: lack of knowledge about environmental questions by the people involved in the project; existence of many uncertainties and lack of understanding about the impact of ecological conception in areas like regulatory compliance, cost reduction, competitive advantage and improved organizational image; lack of consensus about how to evaluate products in environmental terms; absence of standards; and belief that environmental objectives necessarily stand in opposition to economic objectives.

Boks (2006) points out some factors that can influence organizational decisions on ecodesign, including: (1) pressure from external sources, including legal requirements; (2) economic questions, especially the influence of other partners in the value chain; (3) perception of consumers about the environmental impact of products; and (4) relevant development of new technologies.

Vercalsteren (2001) suggests that each firm must evaluate its own potential to apply ecodesign practices by considering internal factors of the company and its business, external factors related to the overall setting in which it operates, and factors related to the product itself. The internal factors include: (1) the firm's level of motivation, especially by senior managers; (2) the firm's ability to innovate and influence the product's specifications; (3) the competition faced by the firm; and (4) the 
existence of ecodesign initiatives in other parts of the firm's sector, which can provide an opportunity for the firm to learn from the experiences of other companies. In turn, the external factors include: (1) legal and regulatory requirements, which can create an important incentive to implement ecological conception practices; (2) characteristics of customers and the market (e.g., whether the market will accept "green" products); and (3) suppliers, whose cooperation is generally essential for the ecological conception process. Besides these aspects, the product must be suitable for ecological conception, i.e., it must have potential to be redesigned based on environmental considerations (Vercalsteren, 2001).

\section{PRINCIPLES AND PRACTICES OF ECODESIGN}

Table 1 below presents a series of ecological conception principles and practices applicable to manufacturing firms, as suggested by Fiksel (1996) and Venzke (2002). This list is not comprehensive, since ecodesign is a dynamic field that it in constant evolution with advances in knowledge and technology.

As can be seen from the list, in the ambit of conception the possibilities are extensive. This is a legacy of a holistic vision of industrial ecology, expanding the more focused concepts from this field to a broader variety of areas. Ecodesign considers a range of environmental concerns regarding the conception of the product, including the impact extraction of raw materials, consumption of energy and questions related to the generation of industrial wastes and sale of products. The ecological approach is preoccupied with the full range of environmental impacts caused over the life cycle of products, running from production to distribution, use and disposal.

Over the past decades, a large variety of ecodesign tools have been developed. In many cases, these tools have arisen from pilot projects and partnerships between private companies and academic research centers. Le Pochat, Bertoluci \& Froelich (2007) identify more than 150 ecodesign tools, and the number is still growing as interest in ecodesign increases.

Despite the wide range of tools available, ecodesign is not always promptly adopted by manufacturing companies, since the tools are often difficult to use (BYGGETH; HOCHSCHORNER, 2006; B ET ; BROMAN; ROB RT, 2007; LE POCHAT; BERTOLUCI; FROELICH, 2007, 2007; LOFTHOUSE, 2006; LUTTROPP; LAGERSTEDT, 2006). 


\begin{tabular}{|c|c|}
\hline Ecodesign Principles & Ecodesign Concepts and Practices \\
\hline $\begin{array}{l}\text { Choose materials with low } \\
\text { environmental impact. }\end{array}$ & $\begin{array}{l}\text { Use raw materials that are as nearly as possible in their natural state. } \\
\text { Avoid combining incompatible materials, which makes it harder to separate the } \\
\text { components for recycling. } \\
\text { Use materials that generate less pollution in the production process, during use of } \\
\text { the product and during recycling or disposal of the product. } \\
\text { Use nontoxic materials in all phases of the product life cycle (production, use and } \\
\text { recycling or disposal). } \\
\text { Use recycled materials or materials that require less energy to produce. } \\
\text { Use materials that allow reuse of components. }\end{array}$ \\
\hline $\begin{array}{l}\text { Create simple and/or } \\
\text { modular products. }\end{array}$ & $\begin{array}{l}\text { Simpler products generally involve lower production costs, reduced utilization of } \\
\text { materials and greater facility of assembly and disassembly. } \\
\text { Create products whose components can be replaced in case of defect or failure, } \\
\text { without the need to replace the entire product. } \\
\text { Make sure components are easy to access. }\end{array}$ \\
\hline $\begin{array}{l}\text { Incinerate wastes instead } \\
\text { of landfill disposal. }\end{array}$ & $\begin{array}{l}\text { Although incineration is a less preferable way to recover value from wastes, it is } \\
\text { still a better option than disposal in landfills, especially when disposal space is } \\
\text { limited. } \\
\text { Assuring that wastes are incinerated helps minimize the risks of hazardous } \\
\text { substances. }\end{array}$ \\
\hline $\begin{array}{l}\text { Reduce } \\
\text { requirements. }\end{array}$ & $\begin{array}{l}\text { In production: Use efficient machines in terms of energy use and adequately } \\
\text { sized, and use energy saving techniques, such as natural lighting. } \\
\text { In distribution: Consider all the energy consumed in the distribution chain, from } \\
\text { purchase of raw materials to delivery to end consumers. } \\
\text { In use: Develop products that incorporate reduced energy consumption } \\
\text { mechanisms, such as more efficient motors, motors that turn off automatically } \\
\text { when the equipment is not in use, and devices that regulate the motor power } \\
\text { according to demand. }\end{array}$ \\
\hline $\begin{array}{l}\text { Use renewable energy } \\
\text { sources. }\end{array}$ & $\begin{array}{l}\text { Use renewable energy sources, such as solar, wind and hydro instead of fossil } \\
\text { fuels. }\end{array}$ \\
\hline $\begin{array}{l}\text { Create multifunctional } \\
\text { products. }\end{array}$ & $\begin{array}{l}\text { Create products that meet more than one need (this often can be done using the } \\
\text { same amount of energy and materials as needed for conventional products with a } \\
\text { single function). } \\
\text { Multifunctionality can be divided into tow types: (1) parallel functionality, in } \\
\text { which the same product is used simultaneously for more than one purpose, and } \\
\text { (2) sequential functionality, in which the product first performs an initial function } \\
\text { and then a secondary function. }\end{array}$ \\
\hline $\begin{array}{l}\text { Develop more durable } \\
\text { products. }\end{array}$ & $\begin{array}{l}\text { Prolonging the useful life of a product makes a significant contribution to } \\
\text { ecoefficiency, since more durability reduces the need to replace the product. }\end{array}$ \\
\hline $\begin{array}{l}\text { Take back packaging } \\
\text { material. }\end{array}$ & $\begin{array}{l}\text { Create a mechanism that enables the package to be recovered for reuse or } \\
\text { recycling, or products that can be refilled. }\end{array}$ \\
\hline $\begin{array}{l}\text { Avoid the use of } \\
\text { hazardous substances. }\end{array}$ & $\begin{array}{l}\text { Eliminate from the production process all substances that can harm the } \\
\text { environment or health of production workers, consumers and recycling workers. } \\
\text { Use water-based components (especially in solvents, adhesives and paints) } \\
\text { instead of materials based on hydrocarbons. }\end{array}$ \\
\hline Prevent accidents & $\begin{array}{l}\text { Apply accident prevention approaches in the conception of new products or } \\
\text { updating of existing ones. }\end{array}$ \\
\hline
\end{tabular}

Table 1: Main Ecodesign Principles and Practices

Source: Fiksel (1996), Venzke (2002). 
According to Lofthouse (2006), tools often fail to be approved "because they do not focus on design, but instead are aimed at strategic management or retrospective analysis of existing products." The author observes that what designers really need is "specific information on areas such as materials and construction techniques to help them become more easily involved in ecodesign projects." The environmental information associated with ecological conception tools is scarce. In most cases, the tools do not provide detailed and specific information that designers find necessary when they work on projects.

Le Pochat, Bertoluci \& Froelich (2007) note that effective use of ecological design tools generally requires collaboration of specialists. This can pose difficulties for many firms, especially small and midsized ones, which often do not have the necessary resources to obtain specialized assistance.

Besides this, the amount of information available on the materials and environmental aspects of products has increased substantially in recent years. This has made it harder and more complicated to use ecological design tools and requires them to be updated frequently (LUTTROPP; LAGERSTEDT, 2006; PIGOSSO et al., 2007).

Companies oriented by ecodesign establish a new relationship in the development process, since they prioritize a careful analysis of the socioenvironmental costs in product development, opting for exchange of materials, productive processes and functional designs. They analyze the pre- and post-consumption stages (reuse or recycling), to improve the overall efficiency of existing products by reducing consumption of raw materials and energy, facilitating the recycling and reuse of components and adjusting ecological technical solutions within systems originally formulated without environmental concerns.

In any event, by means of technical-productive innovation ecodesign creates new products and services that are more ecologically friendly than traditional ones, in search of environmental quality. This process, however, requires time, because it involves the difficulty of inserting these products in a cultural picture dominated by different values. Nevertheless, this innovation manages to develop new scenarios, promoting new quality criteria that are more environmentally sustainable, socially acceptable, economically feasible and culturally attractive.

\section{MATERIALS AND METHODS}

Any research method involves three categories: objectives, procedures and approach to the problem. Regarding the objective, this study is descriptive, because it describes the 
impacts of business on the environment. With respect to procedure, which involves a decision on how the data will be collected, we used a survey. And on the matter of approach to the problem, this is a quantitative study, since we used statistical instruments both in the collection and treatment of the data (RAUPP; BEUREN, 2006).

In line with McDaniel \& Gats (2003), we adopted a non-probabilistic sample, based on convenience. According to Lima (2004), non-probabilistic samples are often used because the entire universe of the target population cannot be sampled.

We obtained our primary date from a semi-structured questionnaire applied in January 2011. We sent 1882 e mail messages hoping to receive a $10 \%$ response rate. The total number of respondents was 340 , or a response rate of $18.0 \%$ of the total population, which was sufficient. The 340 respondents answered all the closed questions.

The questionnaire contained closed (dichotomous) multiple-choice evaluation questions, factual questions, opinion questions and intention questions, as described by Lima (2004). All told, the questionnaire had 15 questions, to obtain data on categorization of the users (profile), considering sex, age, education, economic sector of work, as well as on perception and use of ecodesign principles and practices, as shown in Table 1.

To analyze the ecodesign principles, we used the binomial test (Table 2), which tests the hypothesis that the answers Yes and No are equally divided (50\% for each), as can be seen from the value 0.50 in the TestProp column. The last column (Asymp. Sig. (2-tailed)) shows whether there is a difference between these percentages (and the significance). Values lower than 0.05 are considered significant, indicating that the percentages are different, while values above 0.05 indicate there is no statistical difference in the percentages, i.e., that the percentages of Yes answers is near that of No responses (near $50 \%$ for each one). 
Binomial Test

\begin{tabular}{|c|c|c|c|c|c|c|}
\hline & & Categ. & $\mathrm{N}$ & $\begin{array}{l}\text { Observed } \\
\text { Prop. }\end{array}$ & $\begin{array}{l}\text { Test } \\
\text { Prop. }\end{array}$ & $\begin{array}{l}\text { Asymp. } \\
\text { Sig. (2- } \\
\text { tailed) }\end{array}$ \\
\hline $\begin{array}{l}\text { Does your company, in } \\
\text { the productive? } \\
\text { procurement process, } \\
\text { choose materials with low } \\
\text { environmental impact? }\end{array}$ & $\begin{array}{l}\text { Group } 1 \\
\text { Group } 2 \\
\text { Total }\end{array}$ & $\begin{array}{l}\text { Yes } \\
\text { No }\end{array}$ & $\begin{array}{r}264 \\
76 \\
340\end{array}$ & $\begin{array}{r}.78 \\
.22 \\
1.00\end{array}$ & .50 & $.000^{\mathrm{a}}$ \\
\hline $\begin{array}{l}\text { Does your company, in } \\
\text { the productive } \\
\text { procurement process, try } \\
\text { to create simplicity and/or } \\
\text { modularity of the } \\
\text { product? }\end{array}$ & $\begin{array}{l}\text { Group } 1 \\
\text { Group } 2 \\
\text { Total }\end{array}$ & $\begin{array}{l}\text { Yes } \\
\text { No }\end{array}$ & $\begin{array}{r}249 \\
91 \\
340\end{array}$ & $\begin{array}{r}.73 \\
.27 \\
.00\end{array}$ & .50 & $.000^{3}$ \\
\hline $\begin{array}{l}\text { Does your company try to } \\
\text { incinerate wastes instead } \\
\text { of discarding them in } \\
\text { landfills? }\end{array}$ & $\begin{array}{l}\text { Group } 1 \\
\text { Group } 2 \\
\text { Total }\end{array}$ & $\begin{array}{l}\text { No } \\
\text { Yes }\end{array}$ & $\begin{array}{r}249 \\
91 \\
340\end{array}$ & $\begin{array}{r}.73 \\
.27 \\
1.00\end{array}$ & .50 & $.000^{\mathrm{a}}$ \\
\hline $\begin{array}{l}\text { Does your company } \\
\text { consistently try to reduce } \\
\text { energy demands? }\end{array}$ & $\begin{array}{l}\text { Group } 1 \\
\text { Group } 2 \\
\text { Total }\end{array}$ & $\begin{array}{l}\text { Yes } \\
\text { No }\end{array}$ & $\begin{array}{r}286 \\
54 \\
340\end{array}$ & $\begin{array}{r}.84 \\
.16 \\
1.00\end{array}$ & .50 & $.000^{\mathrm{a}}$ \\
\hline $\begin{array}{l}\text { Does your company try to } \\
\text { use renewable energy } \\
\text { sources? }\end{array}$ & $\begin{array}{l}\text { Group } 1 \\
\text { Group } 2 \\
\text { Total }\end{array}$ & $\begin{array}{l}\text { Yes } \\
\text { No }\end{array}$ & $\begin{array}{r}258 \\
82 \\
340\end{array}$ & $\begin{array}{r}.76 \\
.24 \\
1.00\end{array}$ & .50 & $.000^{3}$ \\
\hline $\begin{array}{l}\text { Does your company } \\
\text { create or purchase } \\
\text { multifunctional products? }\end{array}$ & $\begin{array}{l}\text { Group } 1 \\
\text { Group } 2 \\
\text { Total }\end{array}$ & $\begin{array}{l}\text { Yes } \\
\text { No }\end{array}$ & $\begin{array}{r}267 \\
73 \\
340\end{array}$ & $\begin{array}{r}.79 \\
.21 \\
1.00\end{array}$ & .50 & $.000^{\mathrm{a}}$ \\
\hline $\begin{array}{l}\text { Does your company } \\
\text { create/purchase more } \\
\text { durable products? }\end{array}$ & $\begin{array}{l}\text { Group } 1 \\
\text { Group } 2 \\
\text { Total }\end{array}$ & $\begin{array}{l}\text { Yes } \\
\text { No }\end{array}$ & $\begin{array}{r}263 \\
77 \\
340\end{array}$ & $\begin{array}{r}.77 \\
.23 \\
1.00\end{array}$ & .50 & $.000^{\mathrm{a}}$ \\
\hline $\begin{array}{l}\text { Does your company take } \\
\text { back product packages for } \\
\text { reuse or recycling? }\end{array}$ & $\begin{array}{l}\text { Group 1 } \\
\text { Group } 2 \\
\text { Total }\end{array}$ & $\begin{array}{l}\text { Yes } \\
\text { No }\end{array}$ & $\begin{array}{r}272 \\
68 \\
340\end{array}$ & $\begin{array}{r}.80 \\
.20 \\
1.00\end{array}$ & .50 & $.000^{\mathrm{a}}$ \\
\hline $\begin{array}{l}\text { Does your company } \\
\text { avoid using hazardous } \\
\text { substances in its } \\
\text { processes? }\end{array}$ & $\begin{array}{l}\text { Group } 1 \\
\text { Group } 2 \\
\text { Total }\end{array}$ & $\begin{array}{l}\text { Yes } \\
\text { No }\end{array}$ & $\begin{array}{r}317 \\
23 \\
340\end{array}$ & $\begin{array}{r}.93 \\
.07 \\
1.00\end{array}$ & .50 & $.000^{\mathrm{a}}$ \\
\hline $\begin{array}{l}\text { Does your company try to } \\
\text { reduce accidents? }\end{array}$ & $\begin{array}{l}\text { Group } 1 \\
\text { Group } 2 \\
\text { Total }\end{array}$ & $\begin{array}{l}\text { Yes } \\
\text { No }\end{array}$ & $\begin{array}{r}330 \\
10 \\
340\end{array}$ & $\begin{array}{r}.97 \\
.03 \\
1.00\end{array}$ & .50 & $.000^{\mathrm{a}}$ \\
\hline
\end{tabular}

a. Based on Z Approximation.

Table 2: Binomial Test/Output from SPSS

Source: Research by the authors. 


\section{PRESENTATION AND DISCUSSION OF THE RESULTS}

The profile of the respondents had the following characteristics: women (52.1\%), 18 to 25 years old (50.3\%), with incomplete college (48.2\%), and workers in commerce or services $(72.4 \%)$, as shown in Table 3.

\begin{tabular}{|c|c|c|}
\hline Sex & Women & $52.1 \%$ \\
\hline Age & 18 to 25 years old & $50.3 \%$ \\
\hline Schooling & Incomplete college & $48.2 \%$ \\
\hline Work & Commerce or services & $72.4 \%$ \\
\hline
\end{tabular}

Table 3: Profile of the Respondents

To assess the significance of the responses, we applied the Chi-square test to check the independence between the questions presented in Table 4. the $\chi^{2}$ coefficient is a measure of the dispersion of two variables on a nominal scale, used for statistical testing. It indicates to what extent the observed values deviate from the expected values, if the two variables are not correlated. The higher the Chi-square value, the more significant the relationship is between the dependent and independent variables.

Table 4 - Hypothesis Test Results

\begin{tabular}{|c|c|c|c|}
\hline Item & Relationship between the Variables & Result & Accept/Reject Ho \\
\hline 1 & $\begin{array}{l}\text { Ho: There is no relation between choosing materials with low } \\
\text { environmental impact and the simplicity and/or modularity of } \\
\text { the product. }\end{array}$ & $\mathrm{p}=0.096$ & $\begin{array}{l}\text { Reject the } \\
\text { hypothesis }\end{array}$ \\
\hline 2 & $\begin{array}{l}\text { Ho: There is no relation between incinerating wastes instead } \\
\text { of discarding them in sanitary landfills and reduction of } \\
\text { energy demands. }\end{array}$ & $\mathrm{p}=0.063$ & $\begin{array}{l}\text { Reject the } \\
\text { hypothesis }\end{array}$ \\
\hline 3 & $\begin{array}{l}\text { Ho: There is no relation between using renewable energy } \\
\text { sources and reduction of energy demands. }\end{array}$ & $\mathrm{p}=0.001$ & $\begin{array}{l}\text { Accept the } \\
\text { hypothesis }\end{array}$ \\
\hline 4 & $\begin{array}{l}\text { Ho: There is no relation between creating multifunctional } \\
\text { products and developing more durable products. }\end{array}$ & $\mathrm{p}=0.001$ & $\begin{array}{l}\text { Accept the } \\
\text { hypothesis }\end{array}$ \\
\hline 5 & $\begin{array}{l}\text { Ho: There is no relation between choosing materials with low } \\
\text { environmental impact and taking back product packages. }\end{array}$ & $\mathrm{p}=0.044$ & $\begin{array}{l}\text { Accept the } \\
\text { hypothesis }\end{array}$ \\
\hline 6 & $\begin{array}{l}\text { Ho: There is no relation between avoiding the use of } \\
\text { hazardous substances and preventing accidents. }\end{array}$ & $\mathrm{p}=0.001$ & $\begin{array}{l}\text { Accept the } \\
\text { hypothesis }\end{array}$ \\
\hline
\end{tabular}

Source: Prepared by the authors.

In the first test, 199 respondents $(58.5 \%)$ stated that their companies choose materials with low environmental impact and try to create simple and/or modular products. It can be seen that companies are facing increasing pressures to reduce the negative environmental impacts of their projects, a fact that appears in the perception of the respondents. This 
growing environmental awareness is generating a more demanding society that wants better environmental performance without extra costs. The question of the choice of materials is fundamental, but it must be understood that this is not always related directly with the question of ecologically correct materials, but rather with the challenge of choosing the best material for a determined purpose. Most materials used these days have a strong impact on the environment, considering their phases of extraction, processing, transport and disposal.

In the second test, 215 respondents $(63.2 \%)$ stated that although their companies try to reduce energy demands, they do not generally incinerate wastes instead of sending them to landfills. This provides further evidence of the collapse of sanitation services in Brazil. Questions over the treatment and disposal of municipal solid waste are still largely neglected by public officials. Nevertheless, despite this relative neglect, recycling is growing. For purpose of recycling, the classification of trash as unusable is relative, since a particular waste material may be useless for some purposes and useful for others, to varying profiles depending on the location of the landfill. Sanitary landfills employ techniques that include placement of impermeable membranes under the trash cells and their daily coverage with soil, collection and treatment of gases for energy generation and treatment of leachate, among other technical-operational procedures. The aim is to prevent the negative aspects of waste disposal, such as proliferation of rats and flies and the associated vector-borne diseases, release of unpleasant odors and visual annoyance of huge trash piles.

In the third test, 247 respondents (72.6\%) declared their companies use renewable energy sources and try to reduce their energy demands. It is important to perceive the awareness revealed by the increasing reliance on renewable energy sources: solar energy (mainly solar panels on top of buildings), wind power (mainly by turbines driven by huge propellers on tall towers), hydropower (generated by releasing water behind dams through turbines) and biomass energy (from burning farm and forest residues and other biodegradable material as well as their use to make ethanol and biodiesel).

In the fourth test, 253 respondents (74.4\%) affirmed that their firms create multifunctional products and develop more durable products. In relation to durability, companies are increasingly trying to maximize value by enhancing the durability of their products and formulating projects aimed at simplicity (simpler forms).

In the fifth test, 205 respondents $(60.3 \%)$ declared that their companies choose materials with low environmental impact and take back packages for reuse or recycling. This perception is important because activities to reduce impacts at the source influence the flow of waste 
before the generation point. Also, besides increasing the life of the product, the reuse of products and packages retards the time in which items are finally discarded as waste. When a product is reused, it can be presumed that this delays the purchase and use of a new product. Reutilization is a waste management method that involves direct employment of a producc to the same purpose for which it was originally conceived: a typical example is the reuse of glass bottles. Reuse is also an effective method to minimize production of wastes by maintaining the items with their original characteristics and functions.

Finally, in the sixth test, 313 respondents (98.7\%) stated their companies avoid using hazardous substances in their productive processes and try to prevent accidents. The term "hazardous" in this context refers to substances that are harmful to human health and the environment. In this respect, this has bearing on the development of new products and processes that satisfy the triple bottom line concept, meaning measurement of the results in economic, environmental and social terms.

\section{FINAL CONSIDERATIONS AND RECOMMENDATIONS}

The growing concern over environmental quality by companies, both due to legal and regulatory requirements and consumer demands, is prompting the emergence of new techniques to help businesses develop and build environmentally sustainable and economically feasible production models. One technique is application of the ecodesign concepts, to integrate environmental aspects in projects for new products.

In view that the objective of this article was to investigate the aspects related to ecodesign practices by firms, the results reinforce what was seen in the theoretical reference section. Within the universe surveyed, the introduction of new technologies, based on ecodesign, can contribute to generate competitive advantages, improve the firm's image and comply with legal and market requirements.

Use of ecodesign principles not only satisfies legal requirements, it also benefits the environment, and consequently society as a whole. It can also be said that the use of ecodesign brings other benefits to companies related to their social image, by announcing their concern for environmental questions. Furthermore, by reducing the use of materials and consumption of energy, its increases their operating profits.

For all these reasons, ecodesign can become a differential for companies, since today's consumers increasingly want products and services that minimize the negative impacts on the 
environment, and sustainable design is one way of satisfying these desires, by finding innovative solutions.

People these days are becoming increasingly aware of the importance of preserving the environment. Instead of thinking only of the present and exploiting nature without restraint and concern for the future problems created by their acts, people are waking up to the fact that our planet is showing signs of exhaustion. In short, people are starting to realize the urgency of the environmental problem and that changes need to be made to avoid the extinction of mankind. Alerted by science, the world today seeks a type of progress that relies on sustainable development. One of the strategies in the respect, without question, is ecodesign, which can contribute to a change in behavior in relation to the environment.

Through changes in the mode of consumption and innovative ideas, ecodesign seeks to ameliorate pollution, reduce waste, and to change the very way nature is observed and utilized. Forward-thinking companies have discovered that ecodesign entails the application of performance criteria based on sustainability, by restructuring the flows of activities and making decisions that help to optimize consumption of natural resources, reduce environmental risks, increase energy efficiency and improve social inclusion, without reducing profitability, which is the final goal of all companies.

This study has some limitations, namely: (a) it is an empirical investigation conducted among people of our relationship network in January 2011, so the results cannot be extended to any other time period, geographic region or group of people; (b) the respondents were invited to answer a specific questionnaire based on the assumption that the responses given really expressed the opinion of the people to whom the questionnaire was addressed electronically, so that only this set of questions was taken into consideration; and (c) the data collected were analyzed by the statistical techniques described above, considered adequate for ordinal data, so that the results of the analyses do not take into account other possible observations that might have resulted from the use of other analytic instruments.

The study is also limited by the following aspects: (a) the sample of respondents was non-probabilistic, so it is not possible to extrapolate the results to other persons; and (b) the results obtained only refer to the set of respondents studied, assuming that the answers to the questions really did reflect the opinion of the respondents. 
To improve the data collection instrument in future studies, we suggest including questions related to the difficulties and motivations for implementing ecodesign practices by companies, as well as to survey the thinking of executives with decision-making power.

\section{REFERENCES}

BAHMED, L.; BOUKHALFA, A.; DJEBABRA, M. Eco-conception in the industrial firms: methodological proposition. Management of Environmental Quality: An International Journal, v. 16, n. 5, p. 530-547, 2005.

BOKS, C. The soft side of ecodesign. Journal of Cleaner Production, v. 14, n. 15/16, p. 1346-1356, 2006.

BYGGETH, S.; BROMAN, G.; ROBÈRT, K. A method for sustainable product development based on a modular system of guiding questions. Journal of Cleaner Production, v. 15, n. 1, p. 1-11, 2007.

BYGGETH, S.; HOCHSCHORNER, E. Handling trade-offs in Ecodesign tools for sustainable product development and procurement. Journal of Cleaner Production, v. 14, n. 15/16, p. 1420-1430, 2006.

CHEHEBE, J. Análise do ciclo de vida de produtos: ferramenta gerencial da ISO 14000. Rio de Janeiro: Qualitymark, 2002.

FIKSEL, J. R. Design for environment: creating eco-efficient products and processes. New York: McGraw-Hill, 1996.

KARLSSON, R.; LUTTROPP, C. EcoDesign: what's happening? An overview of the subject area of EcoDesign and of the papers in this special issue. Journal of Cleaner Production, v. 14 , n. 15/16, p. 1291-1298, 2006.

KAZAZIAN, T. Haverá a idade das coisas leves: design e desenvolvimento sustentável. São Paulo: Senac, 2005.

LE POCHAT, S.; BERTOLUCI, G.; FROELICH, D. Integrating ecodesign by conducting changes in SMEs. Journal of Cleaner Production, v. 15, n. 7, p. 671-680, 2007.

LIMA, M. C. Monografia: a engenharia da produção acadêmica. São Paulo: Saraiva, 2004.

LOFTHOUSE, V. Ecodesign tools for designers: defining the requirements. Journal of Cleaner Production, v. 14, n. 15/16, p. 1386-1395, 2006.

LUTTROPP, C.; LAGERSTEDT, J. Ecodesign and the ten golden rules: generic advice for merging environmental aspects into product development. Journal of Cleaner Production, v. 14, n. 15/16, p. 1396-1408, 2006.

MAXWELL, D.; SHEATE, W.; VAN DER VORST, R. Functional and systems aspects of the sustainable product and service development approach for industry. Journal of Cleaner Production, v. 14, n. 17, p. 1466 - 1479, 2006.

MCDANIEL, C.; GATS, R. Pesquisa de marketing. São Paulo: Pioneira, 2003. 
PIGOSSO, D. C. A. et al. Ecodesign methods focused on remanufacturing. Journal of Cleaner Production, v. 18, n. 1, p. 21-31, 2010.

RAO, P. Greening production: a South-East Asian experience. International Journal of Operations \& Production Management, v. 24, n. 3, p. 289-320, 2004.

RAUPP, F. M.; BEUREN, I. M. Metodologia da pesquisa aplicável às Ciências Sociais. In: BEUREN, I. M. (Coord.). Como elaborar trabalhos monográficos em Contabilidade: teoria e prática. São Paulo: Atlas, 2006. p. 76-97. cap. 3.

THEYEL, G. Management practices for environmental innovation and performance. International Journal of Operations \& Production Management, v. 20, n. 2, p. 249-266, 2000 .

VENZKE, C. A situação do ecodesign em empresas moveleiras da Região de Bento Gonçalves-RS: análise das posturas e práticas ambientais. 2002. Dissertação (Mestrado em Administração) - Universidade Federal do Rio Grande do Sul (UFRGS), Porto Alegre (RS), 2002. Disponível em:

<http://www.lume.ufrgs.br/bitstream/handle/10183/2086/000314080.pdf?sequence=1 >. Acesso em: 14 jan. 2011.

VERCALSTEREN, A. Integrating the ecodesign concept in small and medium-sized enterprises. Environmental Management \& Health, v. 12, n. 4, p. 347, 2001. 